\title{
Effect of temperature on pollen germination for several Rosaceae species: influence of freezing conservation time on germination patterns
}

\author{
Roberto Beltrán ${ }^{\text {Corresp., } 1}{ }^{1}$, Aina Valls ${ }^{1}$, Nuria Cebrián ${ }^{1}$, Carlos Zornoza ${ }^{1}$, Francisco José García Breijo ${ }^{1}$, José Reig ${ }^{2}$, \\ Alfonso B Garmendia ${ }^{3}$, Hugo Basilio Merle ${ }^{1}$ \\ ${ }^{1}$ Departamento de Ecosistemas Agroforestales, Universidad Politécnica de Valencia, Valencia, Spain \\ 2 Instituto Cavanilles de Biodiversidad y Biología Evolutiva, Universidad de Valencia, Valencia, Spain \\ 3 Instituto Agroforestal Mediterráneo, Universidad Politécnica de Valencia, Valencia, Valencia, Spain \\ Corresponding Author: Roberto Beltrán \\ Email address: robelmar@upvnet.upv.es
}

Between February 2018 and April 2018, flowers were collected from eight Rosaceae species. Flowers were kept in a freezer at $-20 \stackrel{\circ}{ } \mathrm{C}$ for three freezing times (Treatment 1 , two months; Treatment 2, four months; Treatment 3, six months). After extracting pollen, in vitro germination was induced in a culture medium and incubated at six different temperatures for $72 \mathrm{~h}$. The percentage of pollen germination, average pollen tube length and maximum pollen tube length were measured. Pollen germination was maximum for all species between $15^{\circ} \mathrm{C}$ and $30^{\circ} \mathrm{C}$. Cydonia oblonga, Malus sylvestris, Prunus avium, Prunus domestica, Prunus dulcis, Prunus persica and Pyrus communis obtained 30-52\%pollen

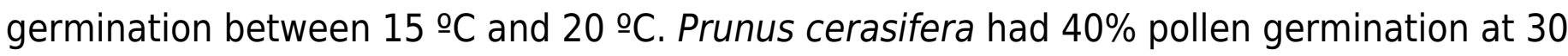

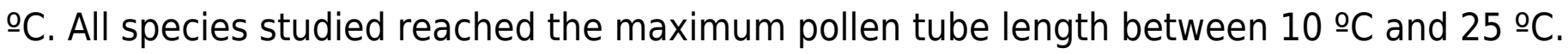
Germination did not change significantly for any of the species with freezing time, but we found significant differences in the three parameters measured between treatments. The highest germination percentages were obtained in Treatment 2 (four months frozen at -20

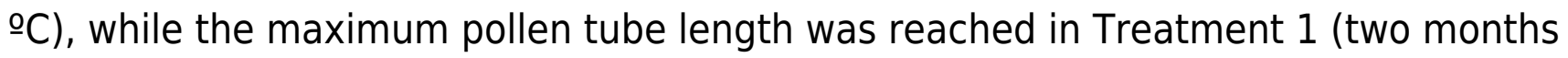
frozen at $-20 \stackrel{\circ}{\circ})$. According to our results, freezing time affected the germination-temperature patterns. This could indicate that studies on the effect of temperature on pollen germination should always be carried out with fresh pollen to obtain more conclusive data. 


\section{Effect of temperature on pollen germination for}

3 several Rosaceae species: influence of freezing

4 conservation time on germination patterns

5

6

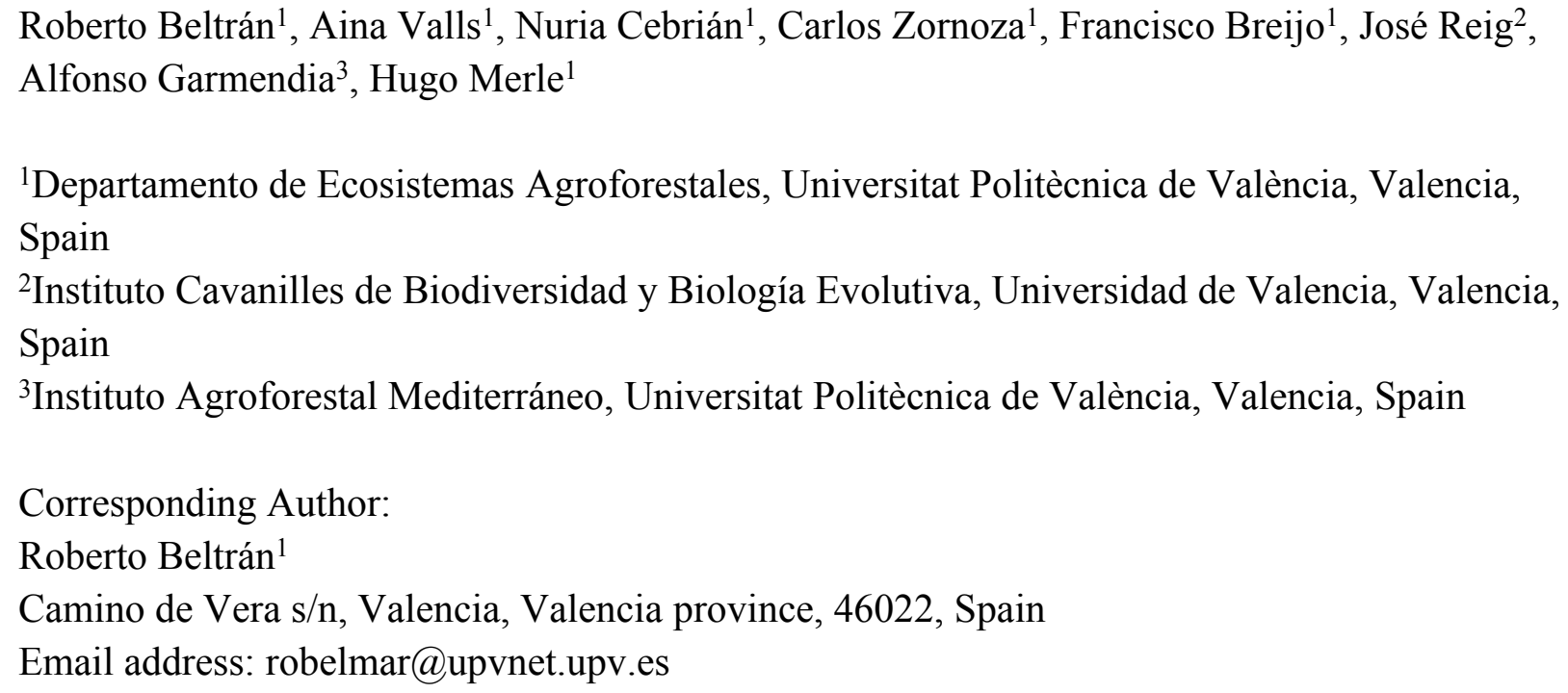

\section{Abstract}

Between February 2018 and April 2018, flowers were collected from eight Rosaceae species. Flowers were kept in a freezer at $-20^{\circ} \mathrm{C}$ for three freezing times (Treatment 1, two months; Treatment 2 , four months; Treatment 3 , six months). After extracting pollen, in vitro germination was induced in a culture medium and incubated at six different temperatures for $72 \mathrm{~h}$. The percentage of pollen germination, average pollen tube length and maximum pollen tube length were measured. Pollen germination was maximum for all species between $15^{\circ} \mathrm{C}$ and $30^{\circ} \mathrm{C}$. Cydonia oblonga, Malus sylvestris, Prunus avium, Prunus domestica, Prunus dulcis, Prunus persica and Pyrus communis obtained $30-52 \%$ pollen germination between $15{ }^{\circ} \mathrm{C}$ and $20^{\circ} \mathrm{C}$. Prunus cerasifera had $40 \%$ pollen germination at $30^{\circ} \mathrm{C}$. All species studied reached the maximum pollen tube length between $10^{\circ} \mathrm{C}$ and $25^{\circ} \mathrm{C}$. Germination did not change significantly for any of the species with freezing time, but we found significant differences in the three parameters measured between treatments. The highest germination percentages were obtained in Treatment 2 (four months frozen at $-20^{\circ} \mathrm{C}$ ), while the maximum pollen tube length was reached in Treatment 1 (two months frozen at $-20^{\circ} \mathrm{C}$ ). According to our results, freezing time affected the germination-temperature patterns. This could indicate that studies on the effect of temperature on pollen germination should always be carried out with fresh pollen to obtain more conclusive data. 
40

41

42

43

44

45

46

47

48

49

50

51

52

53

54

55

56

57

58

59

60

61

62

63

64

65

66

67

68

69

70

71

72

73

74

75

76

77

78

79

80

81

82

83

\section{Introduction}

All Rosaceae species present some common characteristics, like actinomorphic and hermaphroditic flowers requiring pollination for fruit formation. This is the case of the subfamilies Maloideae (apples, pears, quinces) and Prunoideae (almonds, cherries, peaches, plums), which depend on fertilization for fruit set (Hegedüs et al., 2012). Specifically, Malus sylvestris (L.) Mill. and Pyrus communis L. are allogamous species that require the presence of pollinators (e.g. bees or bumblebees) for obtaining higher yields (Stern et al., 2004). Other species such as Prunus avium (L.) L., Prunus domestica L. and Prunus persica (L.) Batsch present autogamous (self-pollinated) and allogamous varieties. In the case of the self-pollinated ones, the yield is related to the fruit set, sometimes requiring the application of hormones to improve it (Webster and Goldwin, 1981; Goldwin and Webster, 1983). In both cases, the pollen grain must be deposited on the stigma and emit the pollen tube. Fertilization occurs when the pollen tube reaches the ovule (Monselise, 2017). Mature ovules have a limited lifetime, so fertilization must occur throughout this time, also called the effective pollination period (Sanzol and Herrero, 2001). It is a complex process, where temperature plays a significant role. It has been observed that an increase in temperature produces both a faster growth of the pollen tube, and an acceleration of the ovule degeneration (Hedhly et al., 2005). Changes in temperature can alter the effective period of pollination, which in turn determines the final fruit set and the yield that the variety can obtain (Sanzol and Herrero, 2001). The weather determines many of the pollination parameters of these species, such as the pollen germination percentage. Thus, it is important to know what the best pollen germination conditions are because reduced germination of pollen may represent important-limiting variables for the crop (Weinbaum et al., 1984).

Likewise, the presence of seeds is decisive for the development of the fruit, so fertilization is one of the processes that must be followed with greater attention in these crops (Monselise, 2017). The main Rosaceae species come from very diverse origins. Malus, Prunus (Pr) and Pyrus (Py) genera come from areas with a temperate climate (Asghar et al., 2012; Castède et al., 2014; Silva et al., 2014). On the contrary, other Rosaceae species are typical of areas with a warmer climate, like Cydonia oblonga Mill. and Prunus cerasifera Ehrh. (Hegedüs and Halasz, 2006; Postman, 2009). Due to this, the temperature ranges that each species requires throughout the flowering and fruiting phases are variable (Monselise, 2017). Climate change can become a limiting factor for some crops in many areas of the planet (Saxe et al., 2001). The global average temperature increase can affect certain regions to a greater extent. In this sense, Iglesias et al. (2012) indicated that a change in European crop patterns is expected, with a decrease in total productivity in Southern Europe and an increase in productivity in Northern Europe. The rise in temperatures could benefit some crops but harm many others. In some areas of the Mediterranean Basin, the progress of crops with higher thermal requirements is already observed. As an example, in some areas of southern Spain such as the provinces of Murcia and Alicante, we can observe at the moment avocado fields. Avocado is a typical crop of warmer areas that is now possible to cultivate in northern latitudes like ours (personal observation). On the contrary, other crops that require cold temperatures could be altered. In these cases, excess heat during flowering and fertilization determines the harvest yield (Hedhly et al., 2005). This could involve the withdrawal to more northern areas of these crops. For all these reasons, knowing the temperature limits of these processes can become an interesting tool to detect possible problems and know if there are species more sensitive than others to these threats. 
84 To date, several studies have been published about the effect of temperature on pollen

85

86

87

88

89

90

91

92

93

94

95

96

97

98

99

100

101

102

103

104

105

106

107

108

109

110

111

112

113

114

115

116

117

118

119

120

121

122

123

124

125

germination in several Rosaceae species, such as Py. communis (Vasilakakis and Porlingis, 1985), apricot (Prunus armeniaca L.) (Egea et al., 1992), Pr. avium (Hedhly et al., 2004), Chinese plum (Prunus mume (Siebold) Siebold \& Zucc.) (Wolukau et al., 2004) Pr. persica (Hedhly et al., 2005), almond (Prunus dulcis (Mill.) D.A.Webb) (Sorkheh et al., 2011b) and various native Iranian almonds like Prunus eleaegnifolia Mill., Prunus orientalis Mill., Prunus lycioides Spach, Prunus reuteri Bioss et Bushe, Prunus arabica Olivier, Prunus glanca Browick and Prunus scoparia Spach (Sorkheh et al., 2011a). According to these studies, most of these species reach the maximum pollen germination percentage or the maximum length of the pollen tube at a temperature close to $20^{\circ} \mathrm{C}$. Recently, Sorkheh et al. (2018) carried out the preincubation of different $P r$. dulcis varieties pollen at different temperatures, thus reproducing the conditions that pollen can face during its dispersion process. Some studies have also compared results among several species, such as Weinbaum et al. (1984), who indicated the different sensitivities of almond and peach pollen to low temperatures. Other studies have been carried out in different botanical family crops like groundnut (Arachis hypogaea L.; Kakani et al. 2002), different pepper species (Capsicum spp.; Reddy and Kakani 2007), Pistacia spp. (Acar y Kakani, 2010), longan (Dimocarpus longan Lour.; Pham et al., 2015) and coconut (Cocos nucifera L.; Hebbar et al., 2018).

Most studies about pollen germination have focused on reviewing the effect of temperature on germination. Reports that have dealt with the most appropriate methodology to produce in vitro pollen germination are less common. Feijó et al. (1995) and Fan et al. (2001) studied the importance of different ions, such as calcium or potassium, for pollen germination in several species. Rosell et al. (1999) improved the pollen germination method in cherimoya (Annona cherimola Mill.) by specifying several aspects of the existing methodology (germination temperature, pre-hydration, etc.). Wolukau et al. (2004) investigated the effect of polyamines and a polyamine synthesis inhibitor on both pollen germination and pollen tube growth in $\mathrm{Pr}$. mume. Burke et al. (2004) worked with cotton (Gossypium spp.) pollen and made several improvements in the existing pollen germination method.

As previously mentioned, a better understanding of the phenology of the crop with respect to temperatures can be of vital importance to precede possible scenarios of Climate Change in the future. The flowering season of the Rosaceae species cited in this study usually lasts a few weeks. In many cases, pollen germination studies cannot be carried out on fresh pollen, due to management and sample availability. It is therefore the case that many of these studies must be carried out with stored freezing pollen. Thus, to be able to carry out new studies and to be able to compare results, it will be very important to know how freezing affects pollen germination. Several authors have reported information on the viability of pollen stored at various temperatures. Many of these studies coincide in stating that the pollen storage at low temperatures like $-20{ }^{\circ} \mathrm{C}$ does not result in a loss of its germination capability. So, Perveen and Khan (2008) studied pollen germination in Malus pumila Mill and indicated that pollen stored at low temperatures had better germination rates than fresh pollen or stored pollen at $4{ }^{\circ} \mathrm{C}$. The same authors analyzed the effect of storage temperatures on pollen germination for species of other botanical families, such as Abelmoschus esculentus L. (Khan and Perveen, 2006a),

Peer] reviewing PDF | (2019:05:38121:3:0:NEW 28 Oct 2019) 
126 Solanum melongena L. (Khan and Perveen, 2006b), Citrullus lanatus L. (Khan and Perveen, 127 2010), Lagenaria siceraria (Molina) Standley (Khan and Perveen, 2011) and Praecitrullus 128 fistulosus (Stocks) Pangalo (Perveen and Khan, 2011). In all cases, pollen samples stored at -20 $129{ }^{\circ} \mathrm{C}$ and $-30{ }^{\circ} \mathrm{C}$ showed a better pollen germination percentage than fresh pollen samples. 130 Likewise, Weinbaum et al. (1984) carried out their study of the effect of cold temperatures on

131

132

133

134

135

136

137

138

139

140

141

142

143

144

145

146

147

148

149

150

151

152

153

154

155

156

157

158

159

160

161

162

163

164

165

166

Pr. dulcis and Pr. persica pollen germination with pollen stored at $-20^{\circ} \mathrm{C}$. Nor was a loss in the germination capability of pollen observed in this study. Therefore, the storage of pollen at low temperatures $\left(-20^{\circ} \mathrm{C},-30^{\circ} \mathrm{C}\right.$ or $\left.-60^{\circ} \mathrm{C}\right)$ is a suitable method for long-term use of pollen. In any case, we found no study about temperature storage conditions for pollen from the most important Rosaceae species, such as apple, cherry, pear or plum trees. For all this, our main research objectives were to check (i) pollen germination capacity at different temperatures, (ii) average and maximum pollen tube length at different temperatures and (iii) the influence of the freezing conservation time for these species.

\section{Materials \& Methods}

Eight Rosaceae species from different origins were selected. Apple (M. sylvestris) and pear (Py. communis) trees are species from temperate climates that better tolerate low temperatures. Both species need higher chilling requirement than other species in the same family (Heide and Prestrud, 2005). Quince (C. oblonga) and cherry plum (Pr. cerasifera) trees come from warmer climates and, therefore, show more tolerance to high temperatures. The other four tree species, cherry (Pr. avium), plum (Pr. domestica), almond (Pr. dulcis) and peach (Pr. persica), are of the intermediate climate origins between both groups. Between February 2018 and April 2018, flowers from all these species were taken at anthesis. Samples were collected at different locations in three Spanish provinces located at different altitudes above sea level (Table 1). All the samples were kept in bags and stored in a freezer at $-20^{\circ} \mathrm{C}$. The freezing times for all the species, were two, four and six months under the conditions mentioned above. According to this, three experimental treatments were established depending on the time when flowers were frozen: Treatment 1 (two months frozen), Treatment 2 (four months frozen) and Treatment 3 (six months frozen).

Flowers were taken from freezers when they were needed to perform assays. They were placed inside a humid chamber at $4{ }^{\circ} \mathrm{C}$ for $2 \mathrm{~h}$ before extracting pollen to achieve its pre-hydration (Mesejo et al., 2006). Pollen grains were extracted and placed in $5 \mathrm{ml}$ of BK medium (a

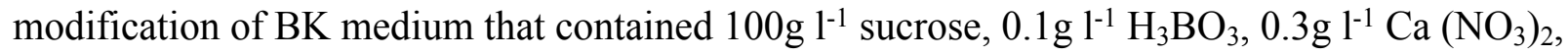
$0.1 \mathrm{~g} \mathrm{l}^{-1} \mathrm{KNO}_{3}$ and $10 \mathrm{~g} \mathrm{l}^{-1}$ agarose; Brewbaker and Kwak, 1963) to induce their germination. The content of two to four anthers per plate was introduced. Plates were incubated for $72 \mathrm{~h}$ in the dark at the same temperatures as those used in other studies: $5{ }^{\circ} \mathrm{C}, 10^{\circ} \mathrm{C}, 15^{\circ} \mathrm{C}, 20^{\circ} \mathrm{C}, 25^{\circ} \mathrm{C}$ and $30{ }^{\circ} \mathrm{C}$ (Weinbaum et al., 1984; Hedhly et al., 2004).

To assess germination capacity, the percentage of germinated pollen grains average pollen tube length and maximum pollen tube lengths were used. It was considered that the pollen had germinated when the length of the pollen tube exceeded the diameter of its pollen grain. The parameters mentioned above were measured for the first 100 pollen grains observed in each

Peer) reviewing PDF | (2019:05:38121:3:0:NEW 28 Oct 2019) 
167 plate. In case of finding a smaller number of grains, the parameters were calculated for the total 168 grains observed.

169 All statistical analyses were executed using R (R Core Team, 2017) and RStudio (RStudio Team

170 2016). ANOVA and Tukey post hoc tests were used to compare between treatments (temperature 171 and freexing times) using "agricolae" package (Mendiburu 2019). When significant differences

172 were found, Levene's test and eta-squared statistics were calculated to assess the homogeneity of 173 variances and the size effect in the ANOVA, respectively. Normality of residuals was tested 174 using Shapiro-Wilk test and looking at density curves. Package "ggplot2" (Wickham 2016) was 175 used to plot the graphics.

176

\section{Results}

178 The maximum pollen germination ranged between $30-52 \%$ for all studied species. Malus sylvestris achieved its maximum germination $(46 \%)$ at $15^{\circ} \mathrm{C}$. Cydonia oblonga, Pr. avium, Pr. domestica, Pr. dulcis, Pr. persica and Py. communis presented their maximum germination at $20^{\circ} \mathrm{C}$. On the other hand, Pr. cerasifera reached its maximum germination $(40 \%)$ at $30^{\circ} \mathrm{C}$ (Figure 1). Significant differences were found for the germination percentages between temperatures only in quince and apple (Tables 2 and 3). For C. oblonga, significant differences were observed between the percentage of grains that germinated at $20^{\circ} \mathrm{C}$ and those that germinated at $5-10^{\circ} \mathrm{C}$ and $25-30{ }^{\circ} \mathrm{C}$ (Table 2). For M. sylvestris, significant differences were observed between $15^{\circ} \mathrm{C}$ and the temperatures of $5{ }^{\circ} \mathrm{C}, 10^{\circ} \mathrm{C}$ and $30^{\circ} \mathrm{C}$ (Table 3 ). The longest pollen tube length was obtained in apple tree, with an average length of 2.5 times the diameter of pollen grain at $10^{\circ} \mathrm{C}$, while no significant differences were observed between temperatures for pollen tube length. Differences in $M$. sylvestris were seen only between the mean pollen tube length at $10^{\circ} \mathrm{C}$ and $25^{\circ} \mathrm{C}$, while the highest values were obtained between $10{ }^{\circ} \mathrm{C}$ and $20^{\circ} \mathrm{C}$ depending on the species. Apple tree was noteworthy, which reached the maximum pollen tube length at $10^{\circ} \mathrm{C}$. No significant differences were observed between temperatures for the maximum pollen tube length, except for $M$. sylvestris with differences between the maximum pollen tube length at $10{ }^{\circ} \mathrm{C}$ and at $25^{\circ} \mathrm{C}$ and for the mean tube length. The maximum pollen tube lengths for all the species were obtained at temperatures between $10^{\circ} \mathrm{C}$ and $20^{\circ} \mathrm{C}$ (Figures 2 and 3 ). Most of the species studied presented the lowest germination percentage (between $8 \%$ and $20 \%$ germination) in Treatment 2 (freezing time of four months). In contrast, Pr. cerasifera and Py. communis gave their lowest pollen germination percentages (21\% and $12.5 \%)$ in Treatments 1 (freezing time of two months) and 3 (freezing time of six months), respectively. For Pr. avium, the lowest percentages were obtained in Treatments 2 and 3, both with about 17\% germination. The lowest values were obtained by Pr. persica and Pr. domestica in Treatment 2, both with a 205 germination percentage of $10 \%$ or lower. The highest value went to C. oblonga in Treatment 3, with more than $30 \%$ germination (Figure 4 ). 
206 All the species obtained their greatest average pollen tube length (1.0 to 2.4) and maximum 207 pollen tube length (1.9 to 3.5) in Treatment 1 (Figures 5 and 6, respectively). For M. sylvestris 208 and Pr. avium, the maximum pollen tube length recorded in Treatment 1 exceeded the pollen 209 grain diameter by more than 3-fold. Likewise, all the species except Pr. cerasifera reached the 210 shortest average and maximum lengths in Treatment 3. In this treatment (freezing time of six 211 months), no maximum pollen tube length exceeded the pollen grain diameter by 1.5-fold.

212 Finally, the pollen germination percentage separated by species and treatments was represented

213 (Figure 7). A wide variability between both treatments and species was observed. Thus, it can be 214 stated that the pollen germination percentage did not follow a clear pattern in the three studied 215 treatments (freezing time).

216

\section{Discussion}

218 Low germination percentages were obtained for all the species at $5{ }^{\circ} \mathrm{C}$ and $10^{\circ} \mathrm{C}$. Sanzol and 219 Herrero (2001) have already indicated how low temperatures slow down pollen growth in several 220 species, such as pear or cherry. The present study verified that the optimum germination 221 temperature for the studied Rosaceae species was variable. M. sylvestris was the species with the 222 highest germination at the lowest temperature $\left(15^{\circ} \mathrm{C}\right)$, which can be accounted for by this tree 223 originating from temperate areas (Agustí, 2010). The results obtained for Pr. cerasifera (higher germination at $30^{\circ} \mathrm{C}$ ) can also be explained by them originating from warmer climate areas (Hegedüs and Halasz, 2006). For the other Prunus species, the obtained results were intermediate and between previous cases, with an optimum germination temperature of $20^{\circ} \mathrm{C}$, which corresponds to this genus' origin from regions with an intermediate climate (Agustí, 2010). The

229

230 results for Malus, Prunus and Pyrus coincided with those reported by other studies. Hedhly et al. (2004) observed how the pollen grain germination percentage in two cherry varieties lowered as temperature rose and obtained the highest germinated grain percentage at $20{ }^{\circ} \mathrm{C}$. Other studies have observed that the optimum temperature for almond and peach pollen germination ranged between $16{ }^{\circ} \mathrm{C}$ and $23{ }^{\circ} \mathrm{C}$ (Weinbaum et al., 1984; Hedhly et al., 2005). Also, Sorkheh et al. (2018) verified how the optimal temperature for pollen germination in various almond genotypes ranged between $20-25^{\circ} \mathrm{C}$. In contrast, Sharafi (2011b) found some variability in the temperature at which the highest germination percentage was recorded for several cultivars of almond, cherry, plum, apricot, prune (Prunus salisina L.) and sour cherry (Prunus cerasus L.). In most evaluations, the obtained germination percentages were lower than $50 \%$. Bolat and Pirlak (1999) tested different sucrose concentrations in their culture media on Pr. armeniaca, Pr. avium and Pr. cerasus, and obtained germination percentages below 50\%. Kakani et al. (2005) measured $20-60 \%$ of pollen germination for Gossypium fresh pollen within a temperature range from $10{ }^{\circ} \mathrm{C}$ to $45^{\circ} \mathrm{C}$. Hedhly et al. (2005) obtained germination percentages of $80 \%-100 \%$ in peach fresh pollen for incubation temperatures like those herein tested. However, Weinbaum et al. (1984) used pollen grains stored at $-20^{\circ} \mathrm{C}$ and did not specify the total storage time before they were used. These authors recorded $100 \%$ peach pollen germination when incubated at $20{ }^{\circ} \mathrm{C}$ and almost $99 \%$ almond pollen germination when incubated at $12{ }^{\circ} \mathrm{C}$. 
246 Wide variability has been observed in the results obtained in relation to the mean and maximum 247 pollen tube lengths. Weinbaum et al. (1984) observed that the pollen tube lengths of almond and 248 peach did not vary despite testing a wide range of temperatures. Sharafi (2011 a, b and c)

249 reported differences for pollen tube lengths in peach, almond, cherry, plum, apple, pear and 250 quince.

251 In this study, the mean pollen tube length of the five studied Prunus species oscillated within a 252 wide range of temperatures $\left(10\right.$ to $\left.25^{\circ} \mathrm{C}\right)$. In other Prunus species, like Pr. cerasus, the longest 253 pollen tube length was observed between $15^{\circ} \mathrm{C}$ and $20^{\circ} \mathrm{C}$ (Cerovic and Ruzic, 1992). In other 254 botanical families, similar results have been found. Sedgley (1977) observed that the pollen tube 255 of avocado progressively grew between $12-17^{\circ} \mathrm{C}$ and $29-33^{\circ} \mathrm{C}$.

256

257

258

259

260

261

262

263

264

265

266

267

268

269

270

271

272

273

274

275

276

277

278

279

280

281

282

283

284 Hedhly et al. (2004) used conserved pollen at $-20^{\circ} \mathrm{C}$ but did not specify the total storage time used under these conditions. Weinbaum et al. (1984) retained pollen at $-20^{\circ} \mathrm{C}$ until further use. In all these cases, the obtained results do not seem to indicate that freezing at $-20^{\circ} \mathrm{C}$ modified normal pollen germination. Other studies carried out on species from other botanical families have indicated that the germinative capacity of freezing pollen is not necessarily worse than that of fresh pollen. For example, Khan and Perveen (2006a) indicated that $A b$. esculentus pollen conserved at $-20^{\circ} \mathrm{C}$ germinated better than the pollen conserved at $4{ }^{\circ} \mathrm{C}$ and fresh pollen. The same authors observed that $S$. melongena pollen conserved at $-20^{\circ} \mathrm{C}$ germinated better than fresh pollen (Khan and Perveen, 2006b) and that Prae. fistulosus pollen maintenance improved at low temperatures $\left(-20\right.$ and $\left.-30{ }^{\circ} \mathrm{C}\right)$ compared to fresh pollen (Perveen and Khan, 2011). Those studies that have attempted to improve the pollen germination methodology have left aside storage conditions when using fresh pollen: different sucrose concentrations (Borlat and Pirlak 1999) and distinct media and temperatures for Arabidopsis thaliana (L.) Heynh. (Boavida and McCormick 2007), cotton (Kakani et al. 2005) or Pr. persica (Hedhly et al. 2005).

Several studies have indicated that freezing fresh flowers at low temperatures is a suitable way to preserve pollen grains in the long term. Khan and Perveen (2014) verified that the viability of pollen from several Citrus species remained at around $50-60 \%$ after four months at $-20{ }^{\circ} \mathrm{C}$. Perveen and Khan (2008) pointed out that M. pumila pollen maintained $65 \%$ germination capability for four months at $-60{ }^{\circ} \mathrm{C}$, but germination capability dropped to $16 \%$ for this same species at $-20^{\circ} \mathrm{C}$.

Towil (2010) reported that pollen storage between $-10^{\circ} \mathrm{C}$ and $-20^{\circ} \mathrm{C}$ can be used to conserve material in the very long term; e.g. one to three years. However, this result should be qualified according to species. Thus, the pollens of Citrus grandis (L.) Osbeck and Citrus medica $\mathrm{L}$. maintained their germination capacity for three years at $-20^{\circ} \mathrm{C}$, while the germination of some grasses likes Lolium multiflorum Lam. or Pennisetum glaucum (L.) R.Br., diminished by less than two months at the same temperature. However, the above-cited author indicated that the germination percentage of some Rosaceae, such as Pr. domestica, remained close to $60 \%$ after 2.5 years at $-20{ }^{\circ} \mathrm{C}$, while $P$. persica achieved germination percentages higher than $65 \%$ with storage times between four and nine years at $-20^{\circ} \mathrm{C}$. 
285 In this study, the germination parameters did not follow a logical pattern between Treatment 1 286 (two months stored at $-20^{\circ} \mathrm{C}$ ), Treatment 2 (four months stored at $-20^{\circ} \mathrm{C}$ ) and Treatment 3 (six 287 months stored at $-20^{\circ} \mathrm{C}$ ). In the case of the pollen tube length, average and maximum length 288 were decreasing from Treatment 1 to Treatment 3 . The storage at low temperatures could modify 289 the pollen response to stress situations. Towil (2010) commented that the pollen storage between $290-10$ and $-20^{\circ} \mathrm{C}$ could lose quality for the long-term storage. So, this observed variation may be 291 due to a decrease in pollen quality as storage time passes. But the pollen germination percentage 292 obtained in the three treatments did not follow a logical pattern. Between Treatment 1 and 293 Treatment 2 there is a decrease in the pollen germination percentage, which coincides with the 294 observed pollen tube length data. Nevertheless, we have observed an increase of the pollen germination percentage for all the studied species, except $P y$. communis, between Treatment 2 and Treatment 3. This change in trend does not correspond to the observed results of pollen tube length between Treatment 2 and Treatment 3. Consequently, the use of pollen from C. oblonga, M. sylvestris, Pr. avium, Pr. cerasifera, Pr. domestica, Pr. dulcis, Pr. persica and Py. communis stored at $-20^{\circ} \mathrm{C}$ for a period of six months could influence the results.

We have observed that the pollen used in much of the studies carried out about the effect of temperature on the germination of pollen has been stored in freezing. It is amply proven that low conservation temperatures do not affect the germination capability of pollen. For this reason, the storage at low temperatures is the most widespread conservation method. Anyway, the different germination patterns observed in our study make us have doubts about their reliability.

So, the freezing temperature and the total freezing time are two factors that should not be taken lightly. Freezing Rosaceae pollen at $-20^{\circ} \mathrm{C}$ is a suitable method for long-term preservation, but it may not be for a reliable study on the effect of temperature. It is easy to assume that the results made on fresh pollen subjected to a temperature scale are directly extrapolated to natural conditions, but it is no longer clear whether those same results obtained when using frozen pollen could be extrapolated with the same reliability. In short, the data we have collected may be important for further studies on pollen germination. Perhaps we should rethink what is the most effective way to store pollen depending on what we are going to use that pollen later. In any case, it would be necessary to compare the germination percentage of pollen preserved at $-20^{\circ} \mathrm{C}$ against fresh pollen in these Rosaceae species.

\section{Conclusions}

The results obtained herein confirmed that freezing Rosaceae pollen at $-20^{\circ} \mathrm{C}$ is a suitable method for its long-term preservation. The pollen of all the studied species maintained its germinative capability throughout the six months in which it was stored at $-20^{\circ} \mathrm{C}$. However, the pollen germination pattern changed depending on the months in which the pollen remained frozen. The results of the three parameters measured (pollen germination, average pollen tube length and maximum pollen tube length) were different in the three treatments studied (two, four and six months stored at $-20^{\circ} \mathrm{C}$ ). One explanation could be that storage at low temperatures could modify the pollen response to stress situations. Consequently, studies that aim to assess the 
325

326

327

328

329

330

331

332

333

334

335

336

337

338

339

340

341

342

343

344

345

346

347

348

349

350

351

352

353

354

355

356

357

358

359

360

361

362

363

effect of germination temperatures should use fresh pollen. On the other hand, it has been observed that the average pollen tube length and maximum pollen tube length are not suitable evaluation parameters due to their wide variability.

\section{References}

Acar, I., Kakani, V.G. 2010. The effects of temperature on in vitro pollen germination and pollen tube growth of Pistacia spp. Scientia Horticulturae 125(4), 569-572.

Asghar, A., Ali, S.M., Yasmin, A. 2012. Effect of climate change on apple (Malus domestica var. ambri) production: A case study in Kotli Satian, Rawalpindi, Pakistan. Pakistan Journal of Botany 44(6), 1913-1918.

Boavida, L.C., McCormick, S. 2007. Temperature as a determinant factor for increased and reproducible in vitro pollen germination in Arabidopsis thaliana. The Plant Journal 52(3), 570-582.

Bolat, İ., Pirlak, L. 1999. An investigation on pollen viability, germination and tube growth in some stone fruits. Turkish Journal of Agriculture and Forestry 23(4), 383-388.

Brewbaker, J.L., Kwack, B.H. 1963. The essential role of calcium ion in pollen germination and pollen tube growth. American Journal of Botany 50, 859-865.

Burke, J.J., Velten, J., Oliver, M.J. 2004. In vitro analysis of cotton pollen germination. Agronomy Journal 96(2), 359-368.

Castède, S., Campoy, J.A., García, J.Q., Le Dantec, L., Lafargue, M., Barreneche, T., Wenden, B., Dirlewanger, E. 2014. Genetic determinism of phenological traits highly affected by climate change in Prunus avium: flowering date dissected into chilling and heat requirements. New Phytologist 202(2), 703-715.

Cerovic, R., Ruzic, D. 1992. Pollen tube growth in sour cherry (Prunus cerasus L.) at different temperatures. Journal of Horticultural Science 67(3), 333-340.

Egea, J., Burgos, L., Zoroa, N., Egea, L. 1992. Influence of temperature on the in vitro germination of pollen of apricot (Prunus armeniaca, L.). Journal of Horticultural Science 67(2), 247-250.

Fan, L.M., Wang, Y.F., Wang, H., Wu, W.H. 2001. In vitro Arabidopsis pollen germination and characterization of the inward potassium currents in Arabidopsis pollen grain protoplasts. Journal of Experimental Botany 52(361), 1603-1614.

Feijó, J.A., Malhó, R., Obermeyer, G. 1995. Ion dynamics and its possible role during in vitro pollen germination and tube growth. Protoplasma 187(1-4), 155-167.

Goldwin, G.K., Webster, A.D. 1983. The cumulative effects of hormone mixtures containing GA3, DPU plus NOXA, NAA or 2, 4, 5-TP on the cropping and flowering of sweet cherry cultivars, Prunus avium L. Journal of Horticultural Science 58(4), 505-516.

Hebbar, K.B., Rose, H.M., Nair, A.R., Kannan, S., Niral, V., Arivalagan, M., Gupta, A., Samsudeen, K., Chandran, K.P., Chowdappa, P., Prasad, P.V.V. 2018. Differences in in vitro pollen germination and pollen tube growth of coconut (Cocos nucifera L.) cultivars 
364

365

366

367

368

369

370

371

372

373

374

375

376

377

378

379

380

381

382

383

384

385

386

387

388

389

390

391

392

393

394

395

396

397

398

399

400

401

402

in response to high temperature stress. Environmental and Experimental Botany 153, 3544.

Hedhly, A., Hormaza, J.I., Herrero, M. 2004. Effect of temperature on pollen tube kinetics and dynamics in sweet cherry Prunus avium (Rosaceae). American Journal of Botany 91(4), 558-564.

Hedhly, A., Hormaza, J.I., Herrero, M. 2005. The Effect of Temperature on Pollen Germination, Pollen Tube Growth, and Stigmatic Receptivity in Peach. Plant Biology 7, 476-483.

Hegedüs, A., Halasz, J. 2006. Self-incompatibility in plums (Prunus salicina Lindl., Prunus cerasifera Ehrh. and Prunus domestica L.). A minireview. International Journal of Horticultural Science 12(2), 137-140.

Hegedűs, A., Lénárt, J., Halász, J. 2012. Sexual incompatibility in Rosaceae fruit tree species: molecular interactions and evolutionary dynamics. Biologia plantarum, 56(2), 201-209.

Heide, O.M., Prestrud, A.K. 2005. Low temperature, but not photoperiod, controls growth cessation and dormancy induction and release in apple and pear. Tree Physiology 25(1), 109-114.

Iglesias, A., Garrote, L., Quiroga, S., Moneo, M. 2012. A regional comparison of the effects of climate change on agricultural crops in Europe. Climatic change, 112(1), 29-46.

Kakani, V.G., Prasad, P.V.V., Craufurd, P.Q., Wheeler, T.R. 2002. Response of in vitro pollen germination and pollen tube growth of groundnut (Arachis hypogaea L.) genotypes to temperature. Plant, Cell and Environment 25(12), 1651-1661.

Kakani, V.G., Reddy, K.R., Koti, S., Wallace, T.P., Prasad, P.V.V., Reddy, V.R., Zhao, D. 2005. Differences in in vitro pollen germination and pollen tube growth of cotton cultivars in response to high temperature. Annals of Botany 96(1), 59-67.

Khan, S. A., Perveen, A. 2006a. Germination capacity of stored pollen of Abelmoschus esculentus L. (Malvaceae) and their maintenance. Pakistan Journal of Botany 38(2), 233.

Khan, S.A., Perveen, A. 2006b. Germination capacity of stored pollen of Solanum melongena L. (Solanaceae) and their maintenance. Pakistan Journal of Botany 38(4), 917.

Khan, S.A., Perveen, A. 2010. In vitro pollen germination capacity of Citrullus lanatus L. (Cucurbitaceae). Pakistan Journal of Botany 42, 681-684.

Khan, S.A., Perveen, A. 2011. Pollen germination capacity and viability in Lagenaria siceraria (Molina) Standley (Cucurbitaceae). Pakistan Journal of Botany 43(2), 827-830.

Khan, S.A., Perveen, A. 2014. In vitro pollen germination of five citrus species. Pakistan Journal of Botany 46(3), 951-956.

Mendiburu, F. 2019. agricolae: Statistical Procedures for Agricultural Research. R package version 1.3-0. Available at https://CRAN.R-project.org/package=agricolae.

Mesejo, C., Martínez-Fuentes, A., Reig, C., Rivas, F, Agustí, M. 2006. The inhibitory effect of $\mathrm{CuSO}_{4}$ on Citrus pollen tuve growth and its application for the production of seedless fruit. Plant Science 170, 37-43.

Monselise, S.P. 2017. Handbook of Fruit Set and Development: 0. CRC press. 
403 Perveen, A., Khan, S.A. 2008. Maintenance of pollen germination capacity of Malus Pumila L.

404

405

406

407

408

409

410

411

412

413

414

415

416

417

418

419

420

421

422

423

424

425

426

427

428

429

430

431

432

433

434

435

436

437

438

439

440

441

442

(Rosaceae). Pakistan Journal of Botany 40(3), 963-966.

Perveen, A., Khan, S.A. 2011. Pollen germination capacity and maintenance of pollen in Praecitrullus fistulosus (Stocks) Pangola (Cucurbitaceae). Pakistan Journal of Botany 43(1), 47-50.

Postman, J. 2009. Cydonia oblonga: The unappreciated quince. Arnoldia 67(1), 2-9.

Pham, V.T., Herrero, M., Hormaza, J.I. 2015. Effect of temperature on pollen germination and pollen tube growth in longan (Dimocarpus longan Lour.). Scientia Horticulturae 197, 470-475.

R Core Team. 2017. R: A Language and Environment for Statistical Computing. Vienna: R Foundation for Statistical Computing. Available at https://www.R-proyect.org/.

RStudio Team. 2016. RStudio: Integrated Development for R. RStudio, Inc., Boston, MA. Available at http://www.rstudio.com/.

Reddy, K.R., Kakani, V.G. 2007. Screening Capsicum species of different origins for high temperature tolerance by in vitro pollen germination and pollen tube length. Scientia Horticulturae 112(2), 130-135.

Rosell, P., Herrero, M., Saúco, V.G. 1999. Pollen germination of cherimoya (Annona cherimola Mill.).: In vivo characterization and optimization of in vitro germination. Scientia Horticulturae 81(3), 251-265.

Sanzol, J., Herrero, M. 2001. The "effective pollination period" in fruit trees. Scientia Horticulturae 90, 1-17.

Saxe, H., Cannell, M. G., Johnsen, Ø., Ryan, M. G., Vourlitis, G. 2001. Tree and forest functioning in response to global warming. New phytologist, 149(3), 369-399.

Sedgley, M. 1977. The effect of temperature on floral behaviour, pollen tube growth and fruit set in the avocado. Journal of Horticultural Science 52(1), 35-141.

Sharafi, Y. 2011a. An investigation on the pollen germination and tube growth in some Prunus persica genotypes and cultivars. African Journal of Microbiology Research 5(14), 2003 2007.

Sharafi, Y. 2011b. In vitro pollen germination in stone fruit tree of Rosaceae family. African Journal of Agricultural Research 6(28), 6021-6026.

Sharafi, Y. 2011c. Investigation on pollen viability and longevity in Malus pumila L., Pyrus commonis L., and Cydonia oblonga L., in vitro. Journal of Medicinal Plants Research 5(11), 2232-2236.

Silva, G.J., Souza, T.M., Barbieri, R.L., Costa de Oliveira, A. 2014. Origin, domestication, and dispersing of pear (Pyrus spp.). Advances in Agriculture, 2014.

Sorkheh, K., Shiran, B., Rouhi, V., Khodambashi, M. 2011a. Influence of temperature on the in vitro pollen germination and pollen tube growth of various native Iranian almonds (Prunus L. spp.) species. Trees 25(5), 809-822.

Sorkheh, K., Shiran, B., Rouhi, V., Khodambashi, M., Wolukau, J. N., Ercisli, S. 2011 b. Response of in vitro pollen germination and pollen tube growth of almond (Prunus dulcis 
443

444

445

446

447

448

449

450

451

452

453

454

455

456

457

458

459

460

461

Mill.) to temperature, polyamines and polyamine synthesis inhibitor. Biochemical Systematics and Ecology 39(4-6), 749-757.

Sorkheh, K., Azimkhani, R., Mehri, N., Chaleshtori, M. H., Halász, J., Ercisli, S., Koubouris, G.C. 2018. Interactive effects of temperature and genotype on almond (Prunus dulcis L.) pollen germination and tube length. Scientia Horticulturae 227, 162-168.

Stern, R.A., Goldway, M., Zisovich, A.H., Shafir, S., Dag, A. 2004. Sequential introduction of honeybee colonies increases cross-pollination, fruit-set and yield of 'Spadona'pear (Pyrus communis L.). The Journal of Horticultural Science and Biotechnology 79(4), 652-658.

Towil, L.E. 2010. Long-term pollen storage. Plant Breeding Reviews 13, 179-207.

Vasilakakis, M., Porlingis, I.C. 1985. Effect of temperature on pollen germination, pollen tube growth, effective pollination period, and fruit set of pear. Hort Science.

Webster, A.D., Goldwin, G.K. 1981. The hormonal requirements for improved fruit setting of plum, Prunus domestica L. cv Victoria. Journal of Horticultural Science 56(1), 27-40.

Weinbaum, S.A., Parfitt, D.E., Polito, V.S. 1984. Differential cold sensitivity of pollen grain germination in two Prunus species. Euphytica 33, 419-426.

Wickham, H. 2016. ggplot2: Elegant Graphics for Data Analysis. Springer-Verlag. New York. Wolukau, J.N., Zhang, S., Xu, G., Chen, D. 2004. The effect of temperature, polyamines and polyamine synthesis inhibitor on in vitro pollen germination and pollen tube growth of Prunus mume. Scientia Horticulturae 99(3-4), 289-299. 


\section{Table $\mathbf{1}$ (on next page)}

O rigin of the samples.

Coordenates and climate data for sampling locations 
1 Table 1: Origin of the samples.

\begin{tabular}{|c|c|c|c|c|c|c|c|c|c|c|}
\hline $\begin{array}{l}\text { Botanical } \\
\text { name }\end{array}$ & $\begin{array}{l}\text { Common } \\
\text { name }\end{array}$ & Variety & Location & Province & $\begin{array}{l}\text { Latitude } \\
\text { (N) }\end{array}$ & $\begin{array}{l}\text { Longitude } \\
\text { (E) }\end{array}$ & Altitude & $\begin{array}{l}\text { Average } \\
\text { temperature }\end{array}$ & $\begin{array}{l}\text { Annual } \\
\text { rainfall }\end{array}$ & Climate* \\
\hline $\begin{array}{l}\text { Cydonia } \\
\text { oblonga }\end{array}$ & Quince & - & Montserrat & Valencia & 39.36044 & -0.54543 & 168 & $16.8^{\circ} \mathrm{C}$ & 432 & BSk \\
\hline $\begin{array}{l}\text { Malus } \\
\text { sylvestris }\end{array}$ & Apple & Golden & Casas-Ibáñez & Albacete & 39.28688 & -1.47133 & 707 & $13.8^{\circ} \mathrm{C}$ & 417 & $\mathrm{Csa}$ \\
\hline $\begin{array}{l}\text { Prunus } \\
\text { avium }\end{array}$ & Cherry & Ambrunes & Casas-Ibáñez & Albacete & 39.28688 & -1.47133 & 707 & $13.8^{\circ} \mathrm{C}$ & 417 & Csa \\
\hline $\begin{array}{l}\text { Prunus } \\
\text { cerasifera }\end{array}$ & Cherry plum & Pissardii & Valencia & Valencia & 39.46975 & -0.37739 & 16 & $17.4^{\circ} \mathrm{C}$ & 445 & BSk \\
\hline $\begin{array}{l}\text { Prunus } \\
\text { domestica }\end{array}$ & Plum & Santa Rosa & Montserrat & Valencia & 39.36044 & -0.54543 & 168 & $16.8^{\circ} \mathrm{C}$ & 432 & BSk \\
\hline $\begin{array}{l}\text { Prunus } \\
\text { dulcis }\end{array}$ & Almond & Marcona & Chóvar & Castellón & 39.85096 & -0.32002 & 415 & $14.8^{\circ} \mathrm{C}$ & 483 & Csa \\
\hline $\begin{array}{l}\text { Prunus } \\
\text { persica }\end{array}$ & Peach & Maruja & Casas-Ibáñez & Albacete & 39.28688 & -1.47133 & 707 & $13.8^{\circ} \mathrm{C}$ & 417 & Csa \\
\hline Pyrus & Pear & Blanquilla & Casas-Ibáñez & Albacete & 39.28688 & -1.47133 & 707 & $13.8^{\circ} \mathrm{C}$ & 417 & Csa \\
\hline
\end{tabular}

2 *Köppen climate classification. BSk, steppe climate; Csa, Mediterranean climate. 
Table 2 (on next page)

ANOVA analysis of the effect of temperature on the percentage of germinatedpollen grains in Cydonia oblonga. 
1 Table 2: The ANOVA analysis of the effect of temperature on the percentage of germinated 2 pollen grains in Cydonia oblonga.

\begin{tabular}{lrrlrrrrr}
\hline Temperature & $\mathrm{N}$ & Mean & HSD & sd & se & skew & kurtosis & Shapiro \\
\hline $5{ }^{\circ} \mathrm{C}$ & 8 & 8.627595 & $\mathrm{~b}$ & 3.7653 & 1.33123 & -2.0485 & 4.9051 & 0.00934 \\
\hline $10^{\circ} \mathrm{C}$ & 9 & 20.575099 & $\mathrm{~b}$ & 13.4543 & 4.48475 & 1.3232 & 2.2126 & 0.16584 \\
\hline $15^{\circ} \mathrm{C}$ & 9 & 24.999794 & $\mathrm{ab}$ & 16.0393 & 5.34642 & 2.7150 & 7.7177 & 0.00008 \\
\hline $20^{\circ} \mathrm{C}$ & 9 & 51.217313 & $\mathrm{a}$ & 28.7425 & 9.58084 & 1.2963 & 0.2574 & 0.01005 \\
\hline $25^{\circ} \mathrm{C}$ & 7 & 18.537415 & $\mathrm{~b}$ & 23.7560 & 8.97891 & 0.5926 & -1.9428 & 0.01457 \\
\hline $30^{\circ} \mathrm{C}$ & 7 & 18.753307 & $\mathrm{~b}$ & 23.4985 & 8.88160 & 0.4113 & -2.6631 & 0.00517 \\
\hline
\end{tabular}

\begin{tabular}{lcccrrrrr} 
& Df & Sum sq & Mean sq & F value & $\operatorname{Pr}(>\mathrm{F})$ & eta.sq & Levene & Shapiro \\
\hline Temperature & 5 & 9060.72 & 1812.1440 & 4.60706 & 0.00187 & 0.34883 & 0.00103 & NA \\
\hline Residuals & 43 & 16913.66 & 393.3409 & NA & NA & NA & NA & 0.00026 \\
\hline
\end{tabular}

$3 \mathrm{~N}$, number of repetitions; HSD, honestly significant difference, different letters mean significant

4 differences for alpha $=0.55$; sd, standard deviation; se, standard error. 


\section{Table 3 (on next page)}

ANOVA analysis of the effect of temperature on the percentage ofgerminated pollen grains in Malussylvestris. 
1 Table 3: The ANOVA analysis of the effect of temperature on the percentage of germinated 2 pollen grains in Malus sylvestris.

\begin{tabular}{llrlrrrrr}
\hline Temperature & $\mathrm{N}$ & Mean & HSD & sd & se & skew & Kurtosis & Shapiro \\
\hline $5{ }^{\circ} \mathrm{C}$ & 9 & 6.447795 & $\mathrm{~b}$ & 2.3557 & 0.7852 & 0.186818 & -1.2641 & 0.67991 \\
\hline $10^{\circ} \mathrm{C}$ & 9 & 14.920536 & $\mathrm{~b}$ & 7.0519 & 2.3506 & 0.44042 & -0.7126 & 0.72167 \\
\hline $15^{\circ} \mathrm{C}$ & 9 & 46.103896 & $\mathrm{a}$ & 40.8139 & 13.6046 & 0.78479 & -1.7173 & 0.00207 \\
\hline $20^{\circ} \mathrm{C}$ & 9 & 36.612823 & $\mathrm{ab}$ & 8.0843 & 2.6947 & 0.64376 & 0.9319 & 0.46971 \\
\hline $25^{\circ} \mathrm{C}$ & 9 & 27.022669 & $\mathrm{ab}$ & 28.7423 & 9.5807 & 0.28891 & -2.0682 & 0.02976 \\
\hline $30^{\circ} \mathrm{C}$ & 9 & 14.682959 & $\mathrm{~b}$ & 15.9491 & 5.3164 & 0.63759 & -1.7144 & 0.01341 \\
\hline
\end{tabular}

\begin{tabular}{lcccrrrrr} 
& Df & Sum sq & Mean sq & F value & $\operatorname{Pr}(>\mathrm{F})$ & eta.sq & Levene & Shapiro \\
\hline Temperature & 5 & 10202.32 & 2040.465 & 4.27038 & 0.00271 & 0.307877 & 0 & NA \\
\hline Residuals & 48 & 22935.26 & 477.8179 & NA & NA & NA & NA & 0.00245 \\
\hline
\end{tabular}

$3 \mathrm{~N}$, number of repetitions; HSD, honestly significant difference, different letters mean significant

4 differences for alpha $=0.55$; sd, standard deviation; se, standard error.

5 
Figure 1

Effect of temperature on the percentage of germinated pollen grains.

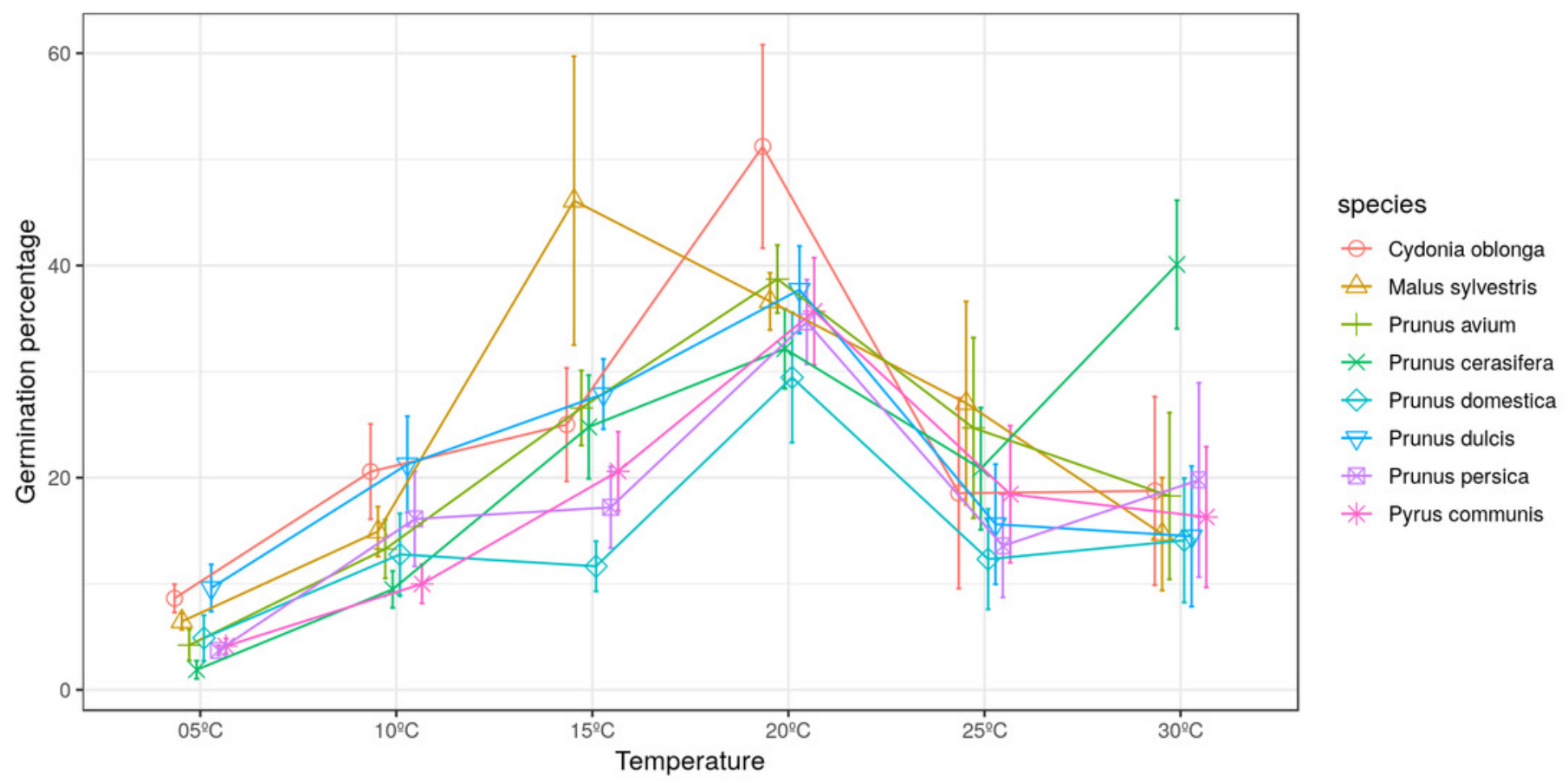


Figure 2

Effect of temperature on the average pollen tube length.

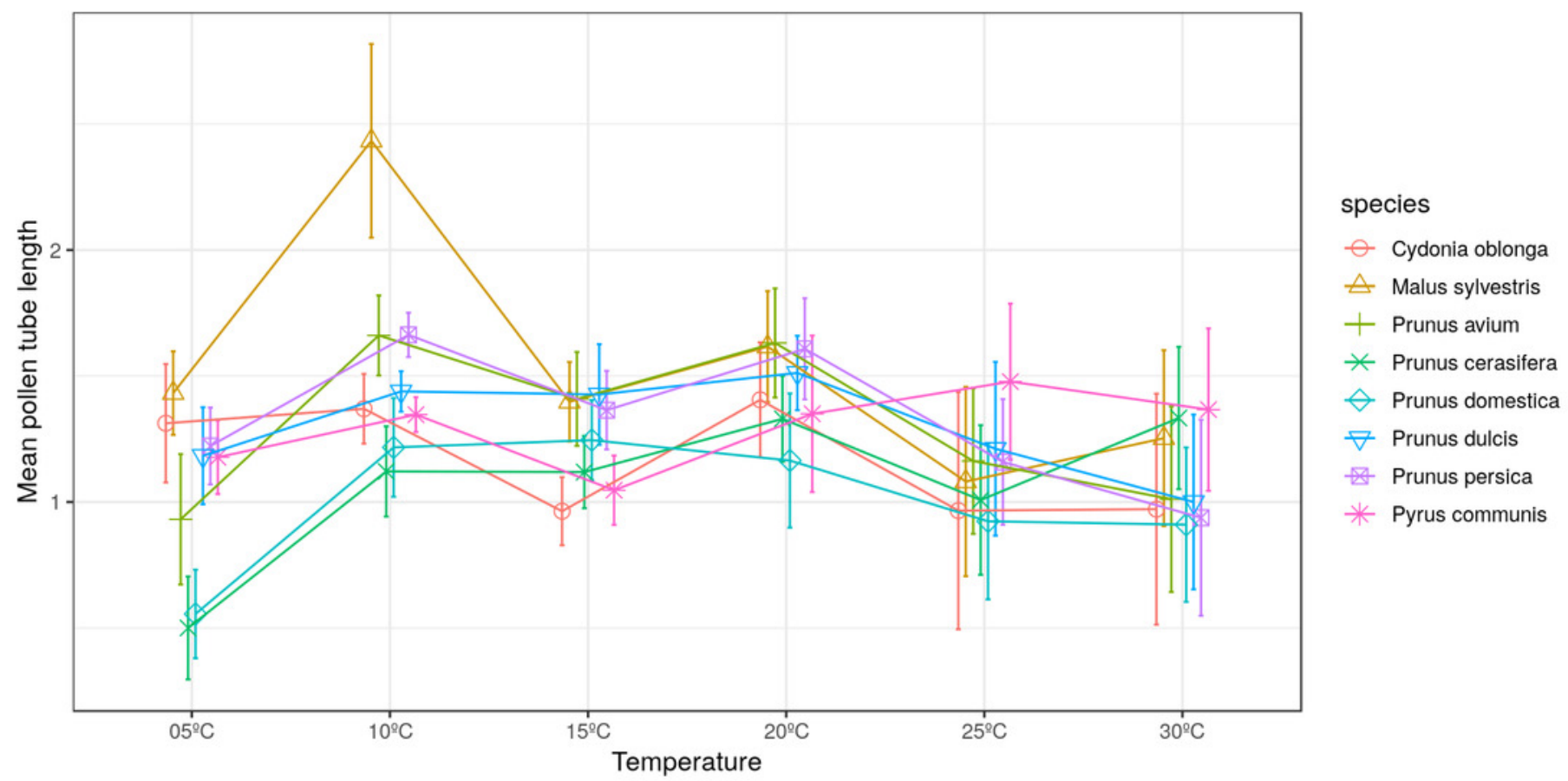


Figure 3

Effect of temperature on the maximum pollen tube length.

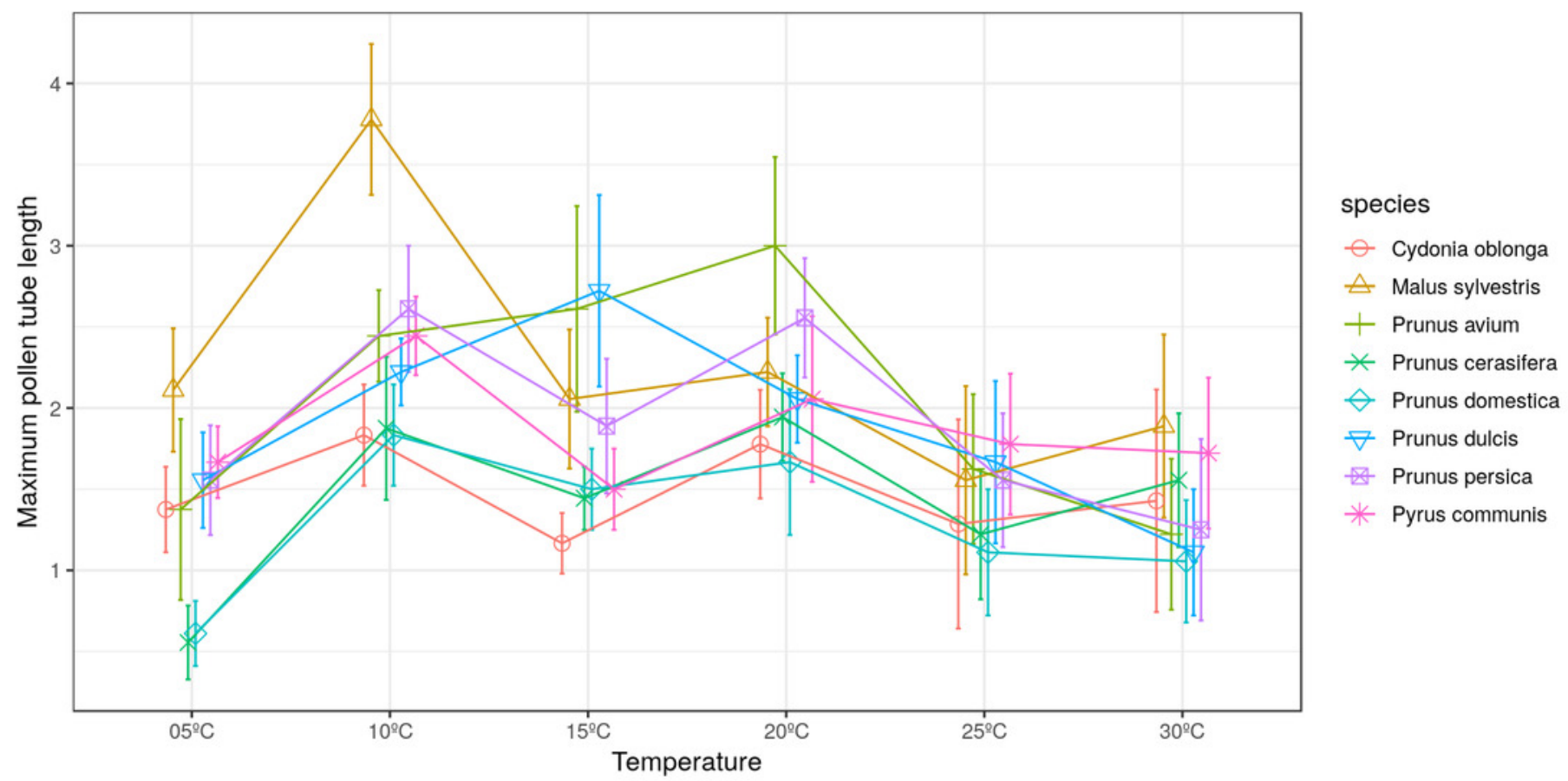


Figure 4

Effect of freezing time on the pollen germination percentage.

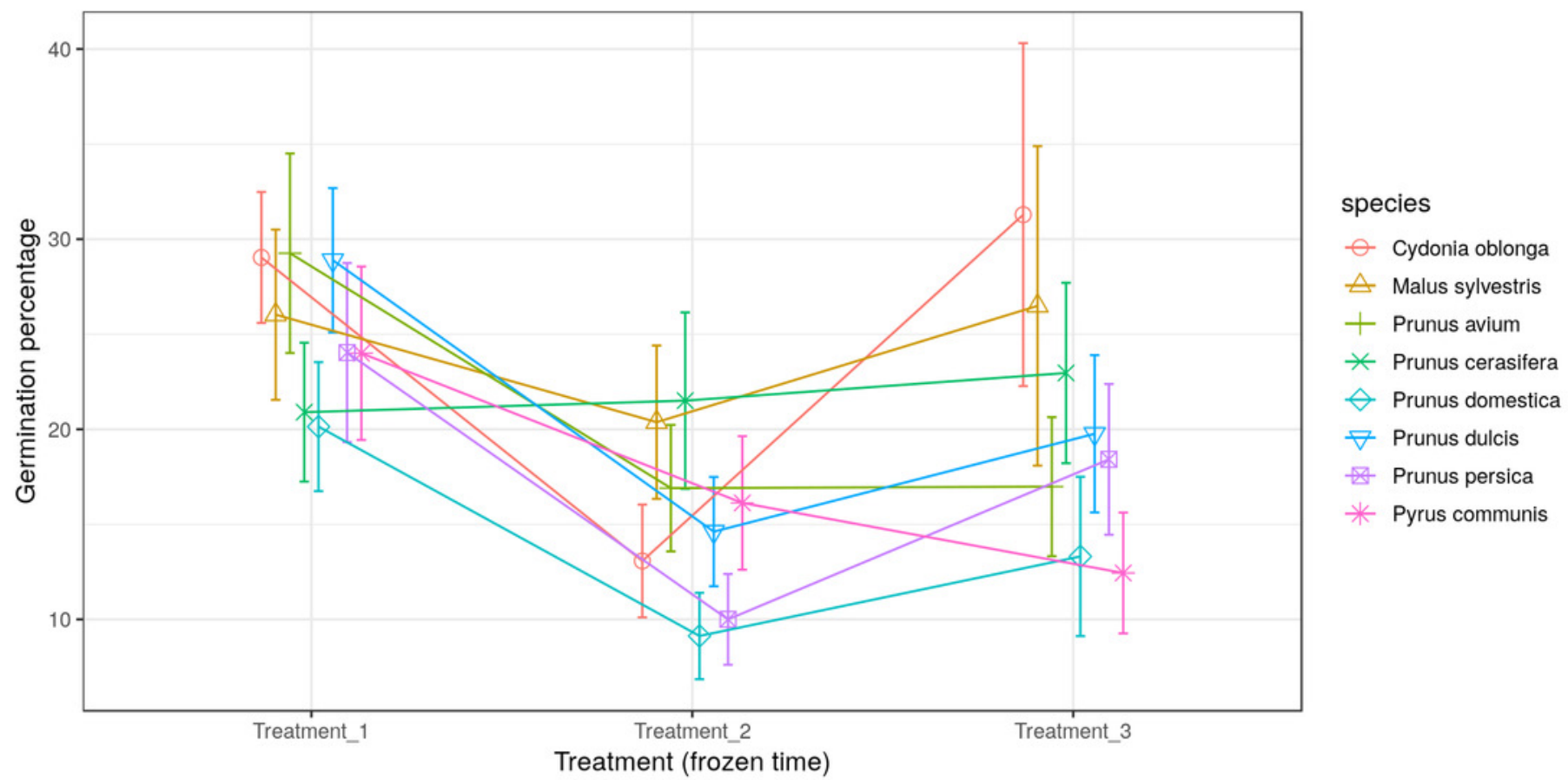


Figure 5

Effect of freezing time on the average pollen tube length.

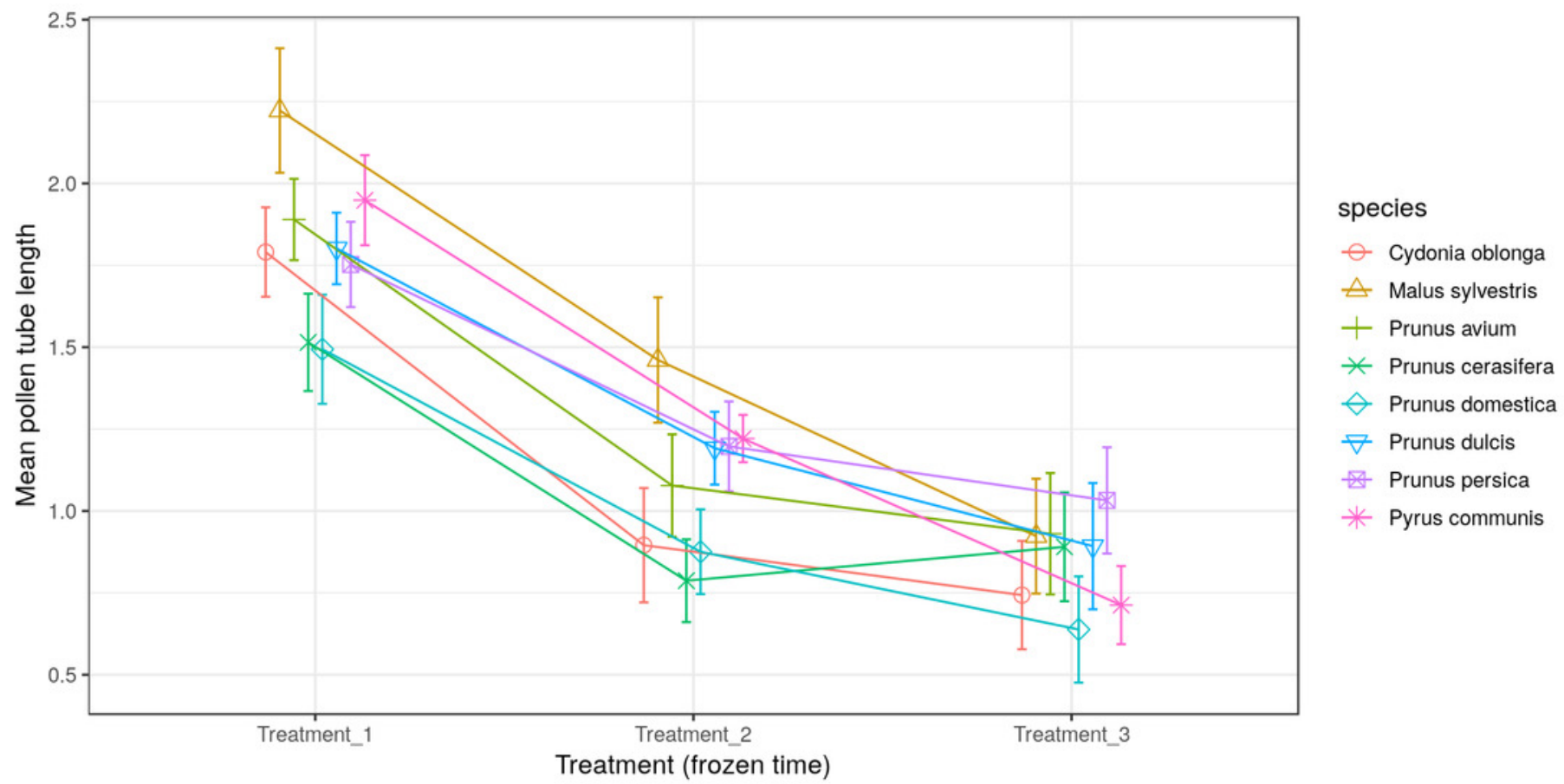


Figure 6

Effect of freezing time on the maximum pollen tube length.

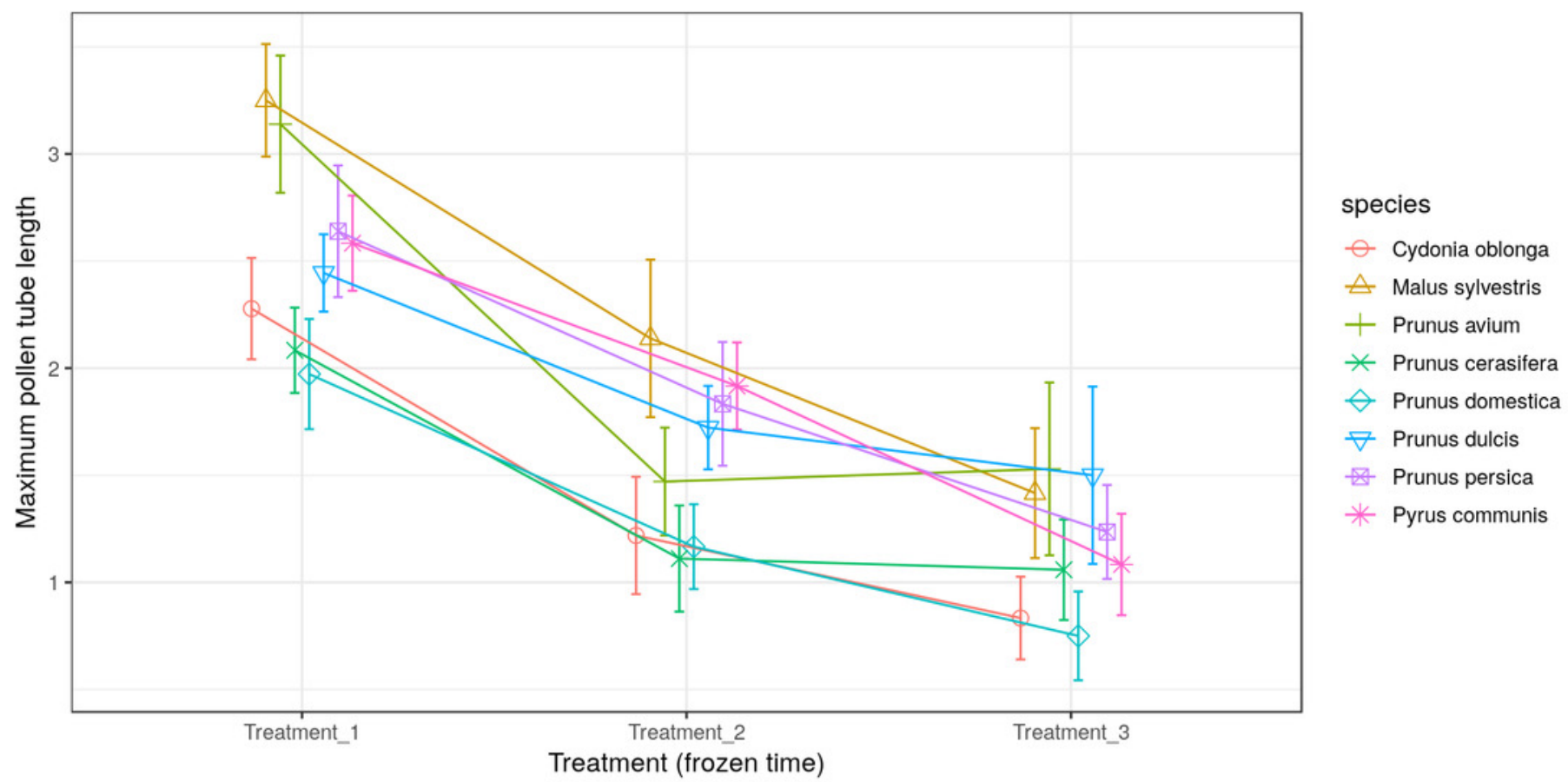




\section{Figure 7}

G ermination percentage by temperatures and treatments (freezing times) for all species.

(A) Data obtained in Cydonia oblonga. (B) Data obtained in Malus sylvestris. (C) Data obtained in Prunus avium. (D) Data obtained in Prunus cerasifera. (E) Data obtained in Prunus domestica. (F) Data obtained in Prunus dulcis. (G) Data obtained in Prunus persica. (H) Data obtained in Pyrus communis. 

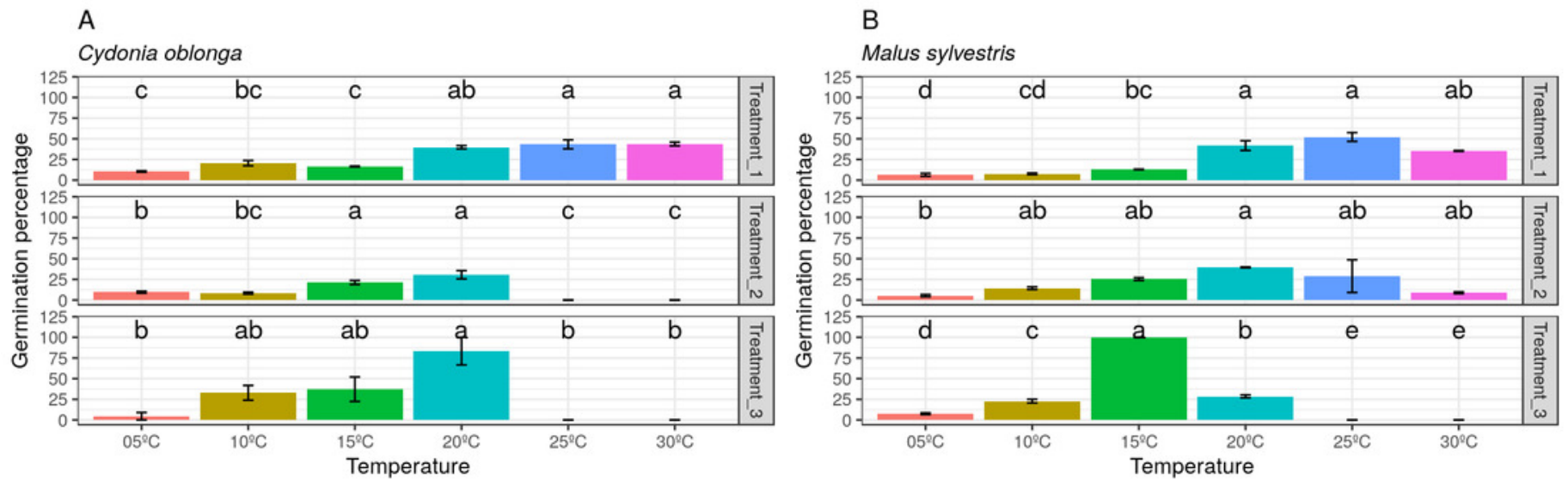

C

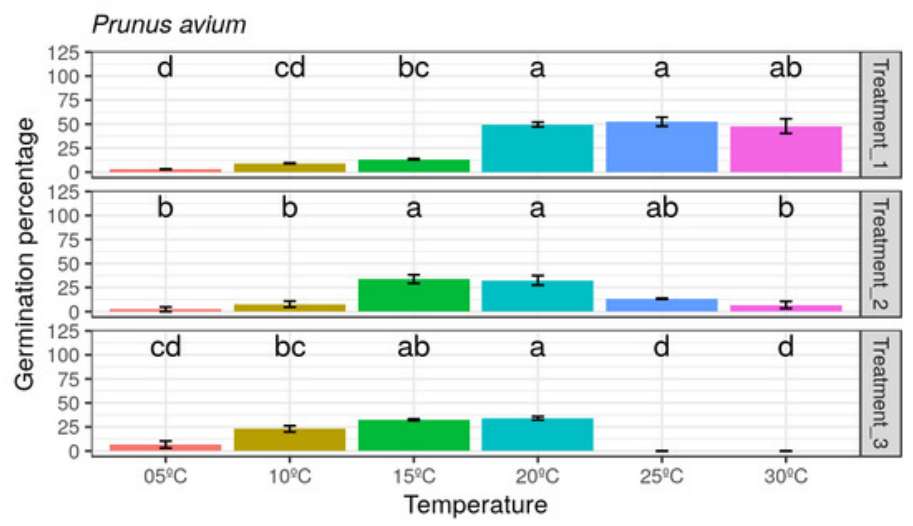

D

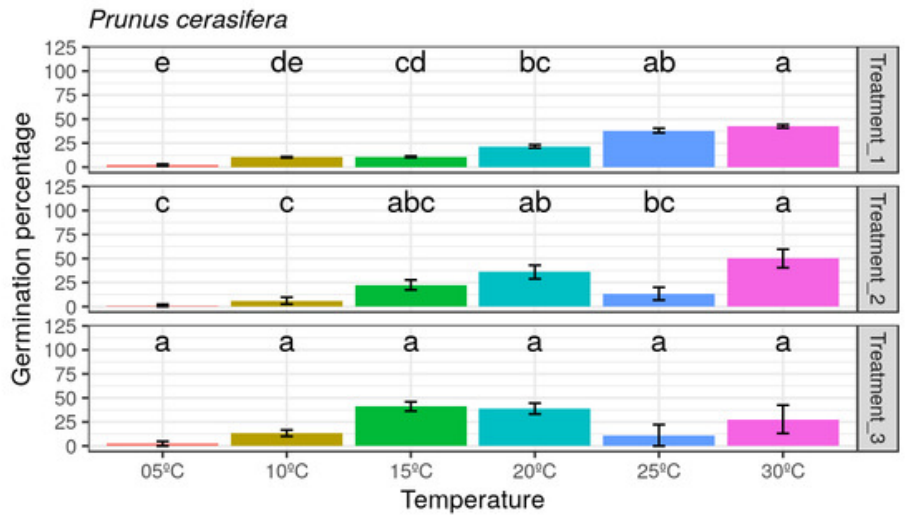

$\mathrm{E}$
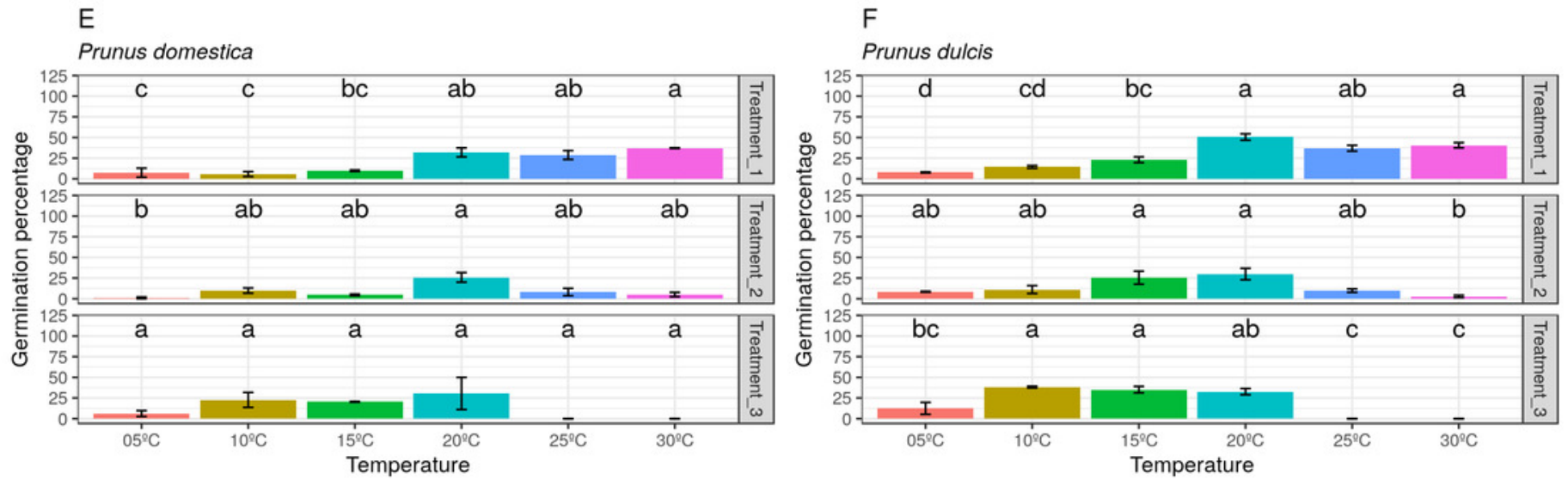

G
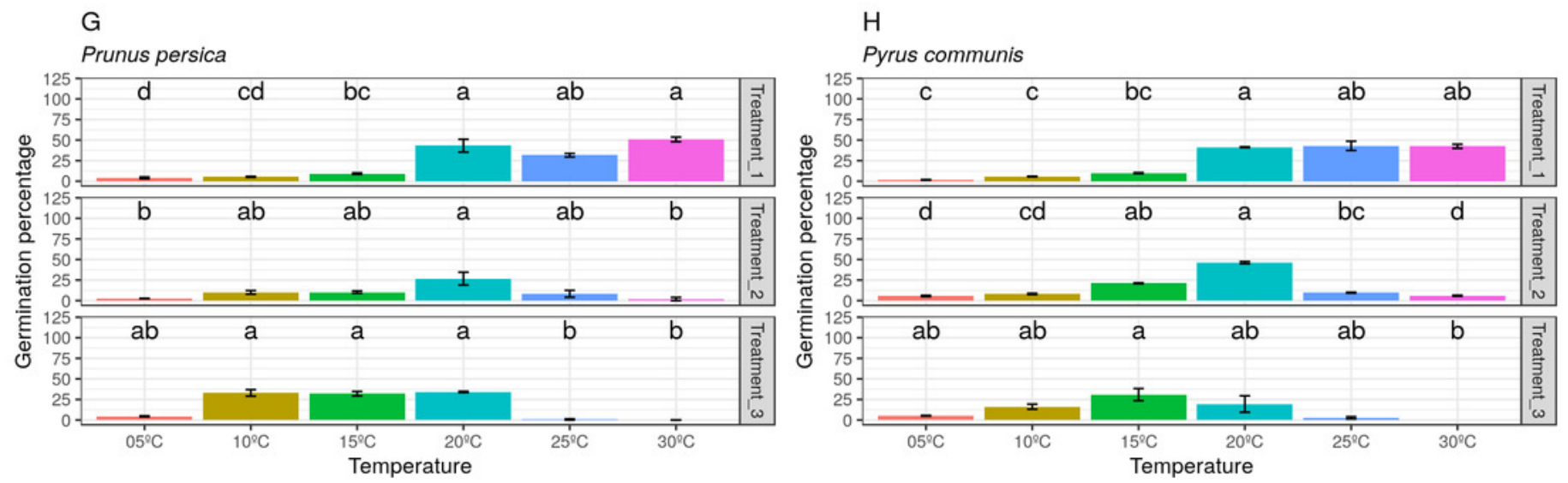